\title{
Effect of Electromagnetic Radiation of Cell Phone Tower on Development of Asiatic Honey Bee, Apis cerana F. (Hymenoptera: Apidae)
}

\author{
Ritu Ranjan Taye ${ }^{1}$, Mukul Kumar Deka ${ }^{2}$, Shimantini Borkataki ${ }^{3}$, \\ Siddharth Panda ${ }^{3}$ and Jaya Gogoi ${ }^{1}$
}

\author{
${ }^{1}$ Department of Entomology, Assam Agricultural University, Jorhat 785013, India \\ ${ }^{2}$ AICRP on Honey Bee and Pollinator, Dept. of Entomology, Assam Agricultural University, \\ Jorhat 785013, India \\ ${ }^{3}$ Faculty of Agriculture, GIBS, Gunupur 765022, India
}

*Corresponding author

\section{A B S T R A C T}

\section{Keywords}

Electromagnetic radiation, Brood area, Honey hoarding capacity, Pollen stores, Queen prolificacy, Apis cerana $\mathrm{F}$.

Article Info

Accepted:

26 July 2018

Available Online:

10 August 2018
The present investigation on the effect of electromagnetic radiation (EMR) of cell phone tower on development of Asiatic honey, Apis cerana F. was studied at Assam Agricultural University, Jorhat during 2012-2014. To quantify the effect of EMR, Apis cerana colonies were placed at varying distance from the cell phone tower, viz. $100 \mathrm{~m}, 200 \mathrm{~m}, 300 \mathrm{~m}, 500 \mathrm{~m}$ and $1000 \mathrm{~m}$ having different radiation level which were measured with the help of 3-Axis RF electromagnetic field meter (model: EMF-819). It was observed that the brood area, honey hoarding capacity, pollen stores and queen prolificacy were significantly higher in colonies placed at $500 \mathrm{~m}$ distance followed by $1000 \mathrm{~m}, 300 \mathrm{~m}$ and $200 \mathrm{~m}$ and least at colonies placed at $100 \mathrm{~m}$ distance from the tower. The results from the present investigation which revealed that the Apis cerana colonies in close proximity to mobile phones towers were most affected by the electromagnetic radiation emitted by the cell phone tower.

\section{Introduction}

Apiculture is a dynamic vocation and has developed into an important industry in India. Traditional apiculture in India is mainly based on Asiatic honey bee, Apis cerana F. It is essential not only for honey and other hive products, but also for the pollination service provided by bees. The economic role of honey bees in worldwide pollination has been estimated around 153 billion Euros (Gallai et al., 2009). Recently a new phenomenon of sudden disappearance of bees with little sign of disease or infestation has been reported from all over the world where the bees simply leave the hive and fail to return. Colony Collapse Disorder (CCD) is the name given to the problem (van Engelsdorp et al., 2009). 
CCD was subjected to pesticides, air pollution and even Genetically Modified Organisms (GMO). In the US, disappearance of bees was associated with the rising network of electromagnetic pollution where bees simply leave the hive and fail to return (Anon., 2007).Studies have brought out evidence to support the theory of colony collapse disorder among honey bees due to electromagnetic radiation from cell phones and their relay towers. The "waggle" dance that bees perform on the honeycomb to communicate with others could be influenced by the radiation, these prevent them from returning back to their hives. The affected hives suddenly left with only queens, eggs and hive bound immature worker bees. Recently, a sharp decline has been noticed in commercial bee population in Kerala, India poising a serious threat to beekeepers, hitting apiculture. Similar cases have been observed in Bihar, Punjab, and other parts of India and have been attributed to increasing electromagnetic pollution in the environment (Kumar, 2010). Currently, there are more than 60 crores cell phone users and nearly 4.3 lakh cell phone towers in India to meet the communication demand. The numbers of cell phones and cell towers are increasing despite of several disadvantages (Kumar, 2010)

As far as research on electromagnetic pollution is concerned, no systematic studies have been conducted on the effect of EMR on development of Asiatic honey bee. So keeping these points in view, the present experiment had been carried out to see the effect of electromagnetic radiation from cell phone tower on development of Apis cerana $\mathrm{F}$.

\section{Materials and Methods}

The study on the effect of electromagnetic radiation of cell phone tower on development of Asiatic honey bee, Apis cerana F. was carried out at Assam Agricultural University,
Jorhat, India $\left(26^{\circ} 46^{\prime} \mathrm{N}\right.$ latitude, $94^{0} 12^{\prime} \quad \mathrm{E}$ longitude and 86.6 meters above sea level). The observations were recorded from December to May during 2012-13 and 201314 at an interval of 15 days. The experiment was conducted by placing Apis cerana colonies at varying distance from the cell phone tower viz:

$\mathrm{T}_{1}=$ Apis cerana colonies placed at $100 \mathrm{~m}$ away from the cell phone tower

$\mathrm{T}_{2}=$ Apis cerana colonies placed at $200 \mathrm{~m}$ away from the cell phone tower

$\mathrm{T}_{3}=$ Apis cerana colonies placed at $300 \mathrm{~m}$ away from the cell phone tower

$\mathrm{T}_{4}=$ Apis cerana colonies placed at $500 \mathrm{~m}$ away from the cell phone tower

$\mathrm{T}_{5}=$ Apis cerana colonies placed at $1000 \mathrm{~m}$ away from the cell phone tower

A 3-Axis RF electromagnetic field meter was used to measure the electromagnetic radiation from tower at varying distances (Table 1). The following biological aspects were recorded during the observation:

\section{Brood area}

The total area under brood comprising eggs, larvae, and pupae was measured in all the experimental colonies with the help of a $5 \times 5$ sq. $\mathrm{cm}$ grid mounted on a comb frame (Sharma and Kumar, 2010). To workout the total brood area, the number of cells comprising eggs, larvae, and pupae were counted within the $5 \times 5 \mathrm{sq}$. $\mathrm{cm}$ paper grid.

\section{Honey hoarding capacity}

The area containing ripe and unripe (sealed and unsealed) nectar was measured in sq. $\mathrm{cm}$ with the help of $5 \times 5 \mathrm{sq} . \mathrm{cm}$ paper grid. 


\section{Pollen stores}

The portion of comb containing cells filled with stored pollen was measured by the grid method expressed in sq. $\mathrm{cm}$.

\section{Queen prolificacy}

Queen prolificacy was measured in terms of egg laying rate of the queen. This has been worked as per the formula given by Sharma and Kumar (2010)

Queen Prolificacy $=$

Total brood area $\left(\mathrm{cm}^{2}\right) \times 4$

21

Where,

$4=$ Number of cells per sq. $\mathrm{cm}$ of comb

$21=$ average time taken for an egg to change into an adult worker

\section{Statistical analysis}

The experimental data were statistically analysed by the method of analysis of variance developed by Fisher (1920's). The data were statistically analysed and the source of variance due to replication, treatment and error were separated out from the total variation. The significance or non-significance of a given variance was determined by calculating the respective values of " $F$ " and by comparing the calculated value of "F" at 5 per cent probability level.

\section{Results and Discussion}

Study on the effect of EMF on colony development of Apis cerana revealed that the brood area in different treatments varied from $815.63-1428.25 \mathrm{~cm}^{2}, \quad 833.75-1493.50 \mathrm{~cm}^{2}$, $859.13-1529.75 \mathrm{~cm}^{2}, \quad 837.38-1609.50 \mathrm{~cm}^{2}$ and $822.88-1558.75 \mathrm{~cm}^{2}$ in colonies placed at $100 \mathrm{~m}, 200 \mathrm{~m}, 300 \mathrm{~m}, 500 \mathrm{~m}$ and $1000 \mathrm{~m}$ respectively. The brood area pertaining to various treatments, the maximum was recorded in the colonies placed at $500 \mathrm{~m}$ $\left(1235.52 \mathrm{~cm}^{2}\right)$ away from the tower followed by $1000 \mathrm{~m}\left(1193.99 \mathrm{~cm}^{2}\right), 300 \mathrm{~m}\left(1170.27 \mathrm{~cm}^{2}\right)$, $200 \mathrm{~m} \quad\left(1136.89 \mathrm{~cm}^{2}\right)$ whereas least were recorded from $100 \mathrm{~m}\left(1102.15 \mathrm{~cm}^{2}\right)$ (Table 2). Sharma and Kumar (2010) also reported significant decline in colonies strength due to EMRs in Apis mellifera. They reported that the area under brood area declined to be $760.17 \mathrm{~cm}^{2}$ in tested colonies which was significantly less than the control $\left(1975.44 \mathrm{~cm}^{2}\right)$. The present findings are in conformity with the views of Mall and Kumar (2014) where they observed that maximum brood area was found in control colonies $\left(560.36 \mathrm{~cm}^{2}\right)$ followed by colonies kept near the tower $\left(537.85 \mathrm{~cm}^{2}\right)$ and lowest brood area $\left(534.81 \mathrm{~cm}^{2}\right)$ was observed in colonies equipped with cell phone. The honey hoarding capacity varied from $427.75-1000.50 \mathrm{~cm}^{2}$, $449.50-1051.25 \mathrm{~cm}^{2}, \quad 431.38-1109.25 \mathrm{~cm}^{2}$, $475.88-1189.00 \mathrm{~cm}^{2}$ and $471.25-1145.50 \mathrm{~cm}^{2}$ in treatments placed at $100 \mathrm{~m}, 200 \mathrm{~m}, 300 \mathrm{~m}$, $500 \mathrm{~m}$ and $1000 \mathrm{~m}$ respectively during the study period. The honey hoarding capacity were recorded to be maximum $\left(851.57 \mathrm{~cm}^{2}\right)$ in the colonies placed at $500 \mathrm{~m}$ followed by $1000 \mathrm{~m}, 300 \mathrm{~m}$ and $200 \mathrm{~m}$ where the honey hoarding capacity was recorded to be $821.52 \mathrm{~cm}^{2}, 788.59 \mathrm{~cm}^{2}$ and $774.54 \mathrm{~cm}^{2}$ respectively, while minimum was recorded in colonies placed at $100 \mathrm{~m}$ distance from the tower $\left(729.53 \mathrm{~cm}^{2}\right)$ (Table 3). Sharma and Kumar (2010) reported that the honey storing ability declined due to loss of returning bees and at the end of the experiment there was neither honey nor pollen or brood and bees in the tested colony resulting in complete loss of the colony. On the contrary, Mall and Kumar (2014) reported that the average honey production was found to be highest (14.43kg/hive) in colonies placed near the tower followed by cell phone equipped colonies $(13.76 \mathrm{~kg} /$ hive $)$, while control 
colonies produced $12.80 \mathrm{~kg} /$ hive in first harvesting. The pollen stores were also significantly affected in various treatments. The mean pollen stores were recorded to be maximum in colonies placed at $500 \mathrm{~m}$ $\left(277.77 \mathrm{~cm}^{2}\right)$ followed by $1000 \mathrm{~m}\left(255.11 \mathrm{~cm}^{2}\right)$, $300 \mathrm{~m}\left(231.70 \mathrm{~cm}^{2}\right)$ and $200 \mathrm{~m}\left(223.39 \mathrm{~cm}^{2}\right)$ and least from colonies at $100 \mathrm{~m}\left(210.86 \mathrm{~cm}^{2}\right)$ (Table 4). The maximum pollen stores $\left(277.77 \mathrm{~cm}^{2}\right)$ were recorded from colonies placed at $500 \mathrm{~m}$ distance and least $\left(210.86 \mathrm{~cm}^{2}\right)$ from colonies at $100 \mathrm{~m}$. The present findings are in conformity with the views of Sharma and Kumar (2010) where they reported decrease in the area under pollen stores from $246.7 \mathrm{~cm}^{2}$ in control to $154.7 \mathrm{~cm}^{2}$ in the colonies exposed to cellphone radiation.

Table.1 EMR frequency on Apis cerana colonies placed at varying distance from the mobile tower during the observation period

\begin{tabular}{|l|c|c|c|c|c|c|}
\hline $\begin{array}{c}\text { EMR } \\
\text { measurement }\end{array}$ & $0 \mathrm{~m}$ & $\mathrm{~T}_{1}(100 \mathrm{~m})$ & $\mathrm{T}_{2}(200 \mathrm{~m})$ & $\mathrm{T}_{3}(300 \mathrm{~m})$ & $\mathrm{T}_{4}(500 \mathrm{~m})$ & $\mathrm{T}_{5}(1000 \mathrm{~m})$ \\
\hline $\begin{array}{l}\text { Electric field } \\
(\mathbf{E}) \mathbf{m V} / \mathbf{m}\end{array}$ & 0 & $159-189$ & $66-127$ & $65-112$ & $63-106$ & $65-108$ \\
\hline
\end{tabular}

Table.2 Effect of electromagnetic radiation of cell phone tower on brood area of Apis cerana colonies placed at varying distance from the tower

\begin{tabular}{|c|c|c|c|c|c|c|c|}
\hline \multirow{2}{*}{ Treatments } & \multicolumn{5}{|c|}{ Brood area of colonies $\left(\mathrm{cm}^{\mathbf{2}}\right)$ at monthly interval } & \multirow{2}{*}{ Mean } \\
\cline { 2 - 9 } & DEC'13 & JAN'14 & FEB'14 & MAR'14 & APR'14 & MAY'14 & \\
\hline $\mathbf{T}_{\mathbf{1}}$ & 815.63 & 928.91 & 929.81 & 1060.31 & 1450.00 & 1428.25 & 1102.15 \\
\hline $\mathbf{T}_{\mathbf{2}}$ & 833.75 & 919.84 & 962.44 & 1082.06 & 1529.75 & 1493.50 & 1136.89 \\
\hline $\mathbf{T}_{\mathbf{3}}$ & 859.13 & 960.63 & 995.06 & 1125.56 & 1551.50 & 1529.75 & 1170.27 \\
\hline $\mathbf{T}_{\mathbf{4}}$ & 837.38 & 1015.00 & 1098.38 & 1207.13 & 1645.75 & 1609.50 & 1235.52 \\
\hline $\mathbf{T}_{\mathbf{5}}$ & 822.88 & 983.28 & 1038.56 & 1158.19 & 1602.25 & 1558.75 & 1193.99 \\
\hline S.Ed. & 12.06 & 15.91 & 32.75 & 35.63 & 35.86 & 40.57 & \\
\hline $\begin{array}{c}\mathbf{C . D} \\
\mathbf{P = 0 . 0 5}\end{array}$ & 26.27 & 34.67 & 71.35 & 78.49 & 79.00 & 87.95 & \\
\hline
\end{tabular}

Table.3 Effect of electromagnetic radiation of cell phone tower on honey hoarding capacity of Apis cerana colonies placed at varying distance from the tower

\begin{tabular}{|c|c|c|c|c|c|c|c|}
\hline \multirow[t]{2}{*}{ Treatments } & \multicolumn{6}{|c|}{ Honey hoarding capacity of colonies $\left(\mathrm{cm}^{2}\right)$ at monthly interval } & \multirow[t]{2}{*}{ Mean } \\
\hline & DEC'13 & JAN'14 & FEB'14 & MAR'14 & APR'14 & MAY'14 & \\
\hline $\mathbf{T}_{1}$ & 427.75 & 561.88 & 723.19 & 750.38 & 913.50 & 1000.50 & 729.53 \\
\hline $\mathbf{T}_{2}$ & 449.50 & 589.06 & 761.25 & 788.44 & 1007.75 & 1051.25 & 774.54 \\
\hline $\mathbf{T}_{3}$ & 431.38 & 584.53 & 744.94 & 831.94 & 1029.50 & 1109.25 & 788.59 \\
\hline $\mathbf{T}_{4}$ & 474.88 & 625.31 & 821.06 & 897.19 & 1102.00 & 1189.00 & 851.57 \\
\hline $\mathbf{T}_{5}$ & 471.25 & 611.72 & 793.88 & 870.00 & 1036.75 & 1145.50 & 821.52 \\
\hline S.Ed & 10.79 & 15.30 & 29.82 & 45.95 & 36.73 & 57.06 & \\
\hline C.D $(P=0.05)$ & 23.54 & 33.33 & 64.96 & 100.11 & 80.03 & 124.31 & \\
\hline
\end{tabular}


Table.4 Effect of electromagnetic radiation of cell phone tower on pollen stores of Apis cerana colonies placed at varying distance from the tower

\begin{tabular}{|c|c|c|c|c|c|c|c|}
\hline \multirow{2}{*}{ Treatments } & \multicolumn{5}{|c|}{ Pollen stores of colonies $\left(\mathrm{cm}^{\mathbf{2}}\right)$ at monthly interval } & \multirow{2}{*}{ Mean } \\
\cline { 2 - 9 } & DEC'13 & JAN'14 & FEB'14 & MAR'14 & APR'14 & MAY'14 & \\
\hline $\mathbf{T}_{\mathbf{1}}$ & 123.25 & 163.13 & 201.19 & 212.06 & 275.50 & 290.00 & 210.86 \\
\hline $\mathbf{T}_{\mathbf{2}}$ & 134.13 & 158.59 & 206.63 & 239.25 & 275.50 & 326.25 & 223.39 \\
\hline $\mathbf{T}_{\mathbf{3}}$ & 145.00 & 172.19 & 206.63 & 250.13 & 290.00 & 326.25 & 231.70 \\
\hline $\mathbf{T}_{\mathbf{4}}$ & 155.88 & 212.97 & 266.44 & 299.06 & 362.50 & 369.75 & 277.77 \\
\hline $\mathbf{T}_{\mathbf{5}}$ & 152.25 & 194.84 & 217.50 & 255.56 & 355.25 & 355.25 & 255.11 \\
\hline $\mathbf{S . E d}$ & 9.68 & 16.50 & 17.59 & 19.40 & 21.18 & 21.50 & \\
\hline $\mathbf{C . D}(\mathbf{P}=\mathbf{0 . 0 5})$ & 21.09 & 35.96 & 38.33 & 42.28 & 46.14 & 46.86 & \\
\hline
\end{tabular}

Table.5 Effect of electromagnetic radiation of cell phone tower on queen prolificacy of Apis cerana colonies placed at varying distance from the tower

\begin{tabular}{|c|c|c|c|c|c|c|c|}
\hline \multirow{2}{*}{ Treatments } & \multicolumn{9}{|c|}{ Egg laying rate of queen (eggs/day)at monthly interval } & \multirow{2}{*}{ Mean } \\
\cline { 2 - 8 } & DEC'13 & JAN'14 & FEB'14 & MAR'14 & APR'14 & MAY'14 & \\
\hline $\mathbf{T}_{\mathbf{1}}$ & 155.36 & 176.93 & 177.11 & 206.11 & 276.19 & 272.05 & 210.63 \\
\hline $\mathbf{T}_{\mathbf{2}}$ & 156.74 & 175.21 & 183.32 & 201.96 & 291.38 & 284.48 & 215.52 \\
\hline $\mathbf{T}_{\mathbf{3}}$ & 163.64 & 182.98 & 197.82 & 214.39 & 295.52 & 291.38 & 224.29 \\
\hline $\mathbf{T}_{\mathbf{4}}$ & 159.50 & 193.33 & 209.21 & 229.93 & 313.48 & 306.57 & 235.34 \\
\hline $\mathbf{T}_{\mathbf{5}}$ & 158.81 & 187.29 & 189.54 & 220.61 & 305.19 & 296.90 & 226.39 \\
\hline $\mathbf{S . E d}$ & 2.30 & 3.03 & 6.24 & 6.78 & 6.81 & 7.69 & \\
\hline $\mathbf{C . D}(\mathbf{P}=\mathbf{0 . 0 5})$ & 5.06 & 6.68 & 13.74 & 14.95 & 15.04 & 16.75 & \\
\hline
\end{tabular}

The egg laying capacity of the queen differed significantly in various treatments. The egg laying rate of the queen varied from 155.36 eggs per day during December 2013 to 313.48eggs per day during April 2014. Queen prolificacy pertaining to various treatments, the maximum 235.34 eggs per day was noticed in colonies at $1000 \mathrm{~m}$ distance followed by $500 \mathrm{~m}$, $300 \mathrm{~m}, 200 \mathrm{~m}$ and $100 \mathrm{~m}$ where the average eggs laid per day were 226.39, 224.29, 215.52 and 210.63 respectively (Table 5). Sharma and Kumar (2010) reported that queen exposed to cell phone radiation produced fewer eggs (144.8) compared to control (376.2). Similar observation were also reported by Sainudeen (2011) where he reported that the queens in the test colonies produced fewer eggs/day (100) compared to the control (350). They reported that there is low egg laying rate in queens exposed to high voltage transmission lines or exposure of the queen bees to cell phone radiation stimulated her to produce only drones. So, the electromagnetic radiation of mobile tower has direct effect on growth and development of honeybee colony.

In conclusion, the results from the present investigation revealed that the Apis cerana colonies in close proximity to mobile phones towers were most affected by the electromagnetic radiation emitted by the tower. The brood area, honey hoarding capacity, pollen stores and queen prolificacy were significantly higher in colonies placed at $500 \mathrm{~m}$ distance followed by $1000 \mathrm{~m}$ and least at colonies placed at $100 \mathrm{~m}$ distance from the tower. Findings of several works reported sharp decline and potential health hazards in honey bee 
populations due to cell phone radiation and could considerably weaken the infrastructure of food webs. The EMRs may harm the health of honeybee in the long run; however, the immediate and direct impact is yet need intensive research to draw a firm conclusion.

\section{Acknowledgements}

The authors take the privilege to express his deep sense of gratitude to AICRP on Honey bees and Pollinators, Assam Agricultural University, Jorhat Centre for providing necessary facilities and scientific help during the experiment.

\section{References}

Anonymous,Bee Alert Technology Inc. National honey bee loss survey updated survey results, June 1 2007, correlation of common pathogens with CCD. http://beealert.blackfoot.net/ beealert/ UpdatedsurveyResultsJune19_2007.pdf.

Balmori A,Electromagnetic pollution from phone masts. Effects on wildlife.Pathophysiology.2009, 16,191199.

Bindokas VP,Gauger JR and Greenberg B,Laboratory investigations of the electrical characteristics of honey bees and their exposure to intense electric fields, Bioelectromagnetics,1989, 10,112.

Faver D, Mobile phone-induced honey bee worker piping. Apiodologie,2011, 42, 270-279.

Gallai N, Salles JM, Settele J and Vaissiere BE, Economic valuation of the vulnerability of world agriculture confronted with pollinator decline. Ecological Economics. 2009, 68, 810-821.
Hamzelous J, Where have all the bees gone? Lancet. 2007, 370, 639.

Kumar G, Report on Cell Tower Radiation. Submitted to Secretary, DOT, Delhi. 2010,

Kumar NR, Verma T and Anudeep, Influence of cell phone radiations on Apis mellifera semen. Journal of Global Biosciences, 2012, 1, 17-19.

Mall P and Kumar Y, Effect of electromagnetic radiation on brooding, honey production and foraging behaviour of European honey bees (Apis mellifera L.). African Journal of Agricultural Research, 2014, 9(13), 1078-1085.

Sainudeen SS, Electromagnetic Radiation (EMR) clashes with honey bees. International Journal of environmental Science. 2011, 1(5), 897-900.

Sainudeen SS, Impact of mobile phone on the density of Honey Bees. Munis Entomology and Zoology. 2011, 6(1), 396-399.

Sharma VP and Kumar NR, Changes in honey bee behaviour and biology under influence of cell phone radiation. Current Science. 2010, 98(10), 13761378.

vanEngelsdorp D, Evans JD, Saegerman C, Mullin C, Haubruge E, Nguyen BK, Frazier M, Frazier J, Cox-Foster D, Chen Y, Underwood R, Tarpy DR and Pettis JS, Colony Collapse Disorder: A Descriptive Study. 2009, Plos one. 4(8), 648:1-17.

Walker MM and Bitterman ME, Attached magnets impair magnetic-field discrimination by honeybee. Journal of Experimental Biology, 1989, 141, 447451.

\section{How to cite this article:}

Ritu Ranjan Taye, Mukul Kumar Deka, Shimantini Borkataki, Siddharth Panda and Jaya Gogoi. 2018. Effect of Electromagnetic Radiation of Cell Phone Tower on Development of Asiatic Honey Bee, Apis cerana F. (Hymenoptera: Apidae). Int.J.Curr.Microbiol.App.Sci. 7(08): 4334-4339. doi: https://doi.org/10.20546/ijcmas.2018.708.454 